\author{
Magistrsko delo • M. A. Work
}

Ivan Lešnik

\title{
Tonski sistemi v slovenski ljudski glasbi
}

Namen magistrske naloge $\mathrm{z}$ naslovom Tonski sistemi $v$ slovenski ljudski glasbi je določiti vpliv temperacije na tonske sisteme $v$ ljudski glasbi na slovenskem etničnem ozemlju. Zanima me ali in s kakšno intenziteto se spreminja odnos do temperacije pri izvajalcih ljudske glasbe in sicer glede na parametre prostora, časa, ter odnosa med vokalno in inštrumentalno domeno.

Izhodišče naloge je delitev slovenskega etničnega ozemlja na nazvočja, kot jih je na podlagi slušnih predstav definiral France Marolt. S pomočjo sodobne računalniško pogojene metodologije se preverja ustreznost omenjene delitve in matematično izražajo značilnosti posameznih tonskih sistemov. Aplikacija računalniškega programa Melodyne, ki ga odlikuje izredna natančnost meritev predstavlja novost v slovenskem etničnem prostoru in raziskovanju ljudske glasbe nasploh.

Rezultati kažejo, da je na določenih področjih izvajalska praksa bolj pod vplivom temperacije kot drugje. Na večini slovenskega etničnega ozemlja je ugotovljeno približevanje temperaciji, kot izjemi sta se pokazali le področji hrvaške Istre in italijanske Rezije. Raziskave v različnih časovnih intervalih so pokazale različno intenzivnost vpliva temperacije, kar je razvidno iz koeficientov odstopanj. Poudarek pri raziskavi je na vokalni praksi zaradi dominacije le-te na slovenskem etničnem ozemlju. Razsežnosti odnosa med vokalno in inštrumentalno domeno so $\mathrm{v}$ nalogi sicer predstavljene, vendar ta aspekt zahteva posebno pozornost in je bo deležen $v$ nadaljevanju raziskovanja.

Magistrska naloga, pri kateri so $\mathrm{v}$ ospredju meritve tonskih razmerij, pomeni zavestno vrnitev $\mathrm{k}$ izhodiščem etnomuzikologije in se izogiba kontekstualnim aspektom, ki so nedvomno $\mathrm{v}$ ospredju pozornosti sodobnih etnomuzikologov. Ob uporabi sodobnih tehničnih pripomočkov registrira in natančno določa zvočne spremembe, ki dejansko niso v domeni slušne prepoznave. $V$ prihodnosti bi raziskavo bilo koristno razširiti na vprašanja metruma in ritma, ter določiti povezave med rezultati sonografskih in kontekstualnih pristopov.

Obranjeno 7. junija 2005 na Filozofski fakulteti Univerze v Ljubljani. 


\section{Tone Systems in Slovene Folk Music}

The aim of the thesis titled Tone Systems in Slovene Folk Music is to determine the influence of the tempered tuning on tone systems of folk music in the Slovenian etbnic territory. I am interested whether and bow strongly the performers of Slovene folk music bave accommodated the tempered tuning in regard to the parameters of place, time, and the relation between vocal and instrumental domains.

The starting point of the thesis is the division of the Slovenian etbnic territory into musical dialects, as defined by France Marolt on the basis of sound images. Modern computer-aided methods were used to verify the relevance of this division and to express mathematically the characteristics of particular tone systems. The application of the computer program Melodyne, which is characterized by extremely precise measurements, is a novelty both in dealing with the Slovenian etbnic territory and in the research of folk music in general.

Results show that the influence of the tempered tuning on the performance practice has been greater in certain areas than in others. Increasing tendency towards the tempered tuning has been noted in the greater part of the Slovenian etbnic territory, with the exception of Istria (Croatia) and Rezija (Italy). Research in different time intervals bas proved a differentiated intensity of the influence of the tempered tuning, wbich is evident from the discrepancy coefficients. The main stress in the researcb bas been given to vocal practice due to its dominance in the Slovenian ethnic territory. The thesis also presents the range of relations between the vocal and instrumental domains, although this aspect calls for more detailed researcb in the future.

The thesis, which concentrates on the measurement of tone relations, points to a conscious retum to the bistorical roots of ethnomusicology, unavoidably neglecting the contextual aspects that are the focus of attention of modern etbnomusicologists. Exploiting main modern technical aids, it records and precisely identifies sound modifications that are not in the range of audible recognition. In the future it would be worthwbile to broaden the research by encompassing the parameters of meter and rhythm, and by relating the results of sonographic and contextual approaches.

Defended on June 7, 2005, Faculty of Arts, University of Ljubljana. 